\title{
Costs related to immunopreventable diseases: Brazil and its geographic areas (immunopreventable diseases' costs in Brazil)
}

\author{
Élide Sbardellotto M. da Costa ${ }^{1 *}$, Adriano Hyeda ${ }^{2}$ and Eliane M. C. P. Maluf ${ }^{3}$
}

\begin{abstract}
Introduction: The occurrence of the immunopreventable diseases in a population global reality.

Objective: To discriminate the direct costs of the hospitalizations from the immunopreventable diseases in the Unified Health System (SUS), in Brazil and their areas, between 2008 and 2018.

Methods: A population, observational, descriptive and retrospective study, with data from the information supplied by the DATASUS website, these data were collected during the 2019.

Results: It was identified 457,479 hospitalizations in the period; with a total of 2,450,870 days of hospital stay, with total costs of $\mathrm{R} \$ 389,243,264.85$. Only the disease mumps presented a growing tendency in whole areas; the chickenpox was decreasing; the illness whooping cough, yellow fever and tetanus were stationary in this period.

Conclusions: The costs related to immunopreventable diseases were relevant in all the Brazil areas, with tendencies different between the geographic areas and between the several illnesses analysed.
\end{abstract}

Keywords: Hospital costs, Communicable diseases, Vaccines, Unified health system

\section{Introduction}

The World Health Organization (WHO) estimates that a fourth of the deaths in children under five years old are caused by preventable diseases [1-7]. According to the international literature [8-10], an important proportion of the health care is attributed

\footnotetext{
* Correspondence: elide.costa@sesa.pr.gov.br

This manuscript was developed at the Federal University of Paraná,

Department of Internal Medicine Post-graduation, at General Carneiro Street,

181, Curitiba, Paraná, Brazil ZIPCODE 80.060-900. This study is a partial

requirement to the obtaining of the title of Phd degree from the main author.

'Department of Internal Medicine Post-graduation, Federal University of

Paraná, General Carneiro Street, 181, Curitiba, Paraná, Brazil

Full list of author information is available at the end of the article
}

to communicable diseases, one in six cases assisted by the primary health care, and about 128,000 hospitalizations ( $84 \%$ in public hospitals) were related to these conditions (data from 2010).

Therefore, it is a national public interest the rising of data by health care in this context of preventable diseases. Other countries already had made similar researches with very relevant data about the Immunizations Programs interfere positively in the reduction of the care costs and of rehabilitation, productivity increase, reduction of work absenteeism, and indirect social impact from these diseases [11, 12]. In this context, it is necessary an analysis of the Brazilian reality of the immunopreventable diseases, considering that the Immunization Program is a national reality [13], and considering the campaigns anti-vaccination and the

(c) The Author(s). 2021 Open Access This article is licensed under a Creative Commons Attribution 4.0 International License, which permits use, sharing, adaptation, distribution and reproduction in any medium or format, as long as you give appropriate credit to the original author(s) and the source, provide a link to the Creative Commons licence, and indicate if changes were made. The images or other third party material in this article are included in the article's Creative Commons licence, unless indicated otherwise in a credit line to the material. If material is not included in the article's Creative Commons licence and your intended use is not permitted by statutory regulation or exceeds the permitted use, you will need to obtain permission directly from the copyright holder. To view a copy of this licence, visit http://creativecommons.org/licenses/by/4.0/ The Creative Commons Public Domain Dedication waiver (http://creativecommons.org/publicdomain/zero/1.0/) applies to the data made available in this article, unless otherwise stated in a credit line to the data. 
fall of the vaccination coverages in all Brazilian geographic area (the national vaccination coverages don't reach the minimum of $95 \%$ of coverage - Table 1) and in the whole world [8].

\section{Methods}

In this manuscript, it was defined to analysis the data regarding the Brazil, discriminated by its geographical official country areas: North, Northeast, Center-west, Southeast and South.

It was accomplished a population study, observational, descriptive, retrospective, with multiple groups and temporary series, with aggregated public data, through information supplied by the public website of the System of information of the Department of the Unified Health System (DATASUS - http://www2.datasus.gov.br/ DATASUS/index.php?area $=02$ ). The research methodology used by the website of DATASUS was established according to the available tools in the consultation system: through the following links: "Information of Health (TABNET)", "Epidemiology and Morbidity"; "SUS Hospital morbidity (SIH/SUS) "; "General hospitalization place - starting from 2008"; "Brazil for Area and Federation Units"; Line = "Area / Federation Units"; Column = it hadn't been "activated", content = "Hospitalizations; Hospitalization approved authorizations (AIH); Total value; Value of the hospital services; Value of the professional services; AIH average value; days of hospital stay; Average days of hospital stay; Deaths; Mortality tax"; available period of January 2008 to December 2018; chapter of CID 10 = "infectious and parasitic diseases"; list of morbidities / CID $10=$ "Neonatal tetanus and other tetanus; Diphtheria; Whooping cough; Yellow fever; Meningococcal disease; Measles; Rubella; Mumps; Human rabies virus; Chickenpox / Herpes Zoster; Acute hepatitis B" (these diseases had been chosen because

Table 1 Description of the immunization coverage, discriminated by each vaccine and by Brazilian geographic area, in the period from 2008 to 2021

\begin{tabular}{|c|c|c|c|c|c|c|}
\hline \multirow[t]{2}{*}{ Vaccine } & \multicolumn{6}{|c|}{ Brazilian geographic area } \\
\hline & North & Northeast & Southeast & South & $\begin{array}{l}\text { Center- } \\
\text { west }\end{array}$ & Total \\
\hline Calmette-Guérin bacillus vaccine (BCG) & 103.62 & 100.08 & 97.81 & 97.71 & 103.68 & 99.55 \\
\hline Hepatitis B vaccine (HBV) in children under 30 days & 72.28 & 72.36 & 71.74 & 67.95 & 79.08 & 72.06 \\
\hline Rotavirus Humano G1P1 vaccine (VORH) & 74.21 & 83.25 & 89.07 & 90.00 & 89.45 & 85.93 \\
\hline Meningococal C vaccine (MenC) & 68.56 & 72.93 & 84.12 & 82.84 & 79.82 & 78.60 \\
\hline Hepatitis B vaccine (HBV) & 84.64 & 90.18 & 93.30 & 93.51 & 93.31 & 91.49 \\
\hline 5-in-1 vaccine (diphtheria, tetanus, whooping cough, Haemaphilus influenzae B, hepatitis B) & 69.09 & 75.73 & 81.03 & 82.82 & 82.38 & 78.58 \\
\hline Pneumococcal 10 vaccine (Pnc10) & 71.10 & 79.35 & 86.34 & 88.50 & 86.36 & 82.98 \\
\hline Poliomielitis 1, 2, 3 vaccine (VIP) & 86.48 & 91.80 & 93.15 & 92.66 & 94.50 & 92.08 \\
\hline Poliomielitis 1,2,3 vaccine in children under 4 years & 45.27 & 52.69 & 73.85 & 84.34 & 73.64 & 65.35 \\
\hline Yellow fever vaccine & 80.29 & 39.64 & 40.37 & 56.10 & 83.75 & 50.10 \\
\hline Hepatitis A vaccine & 58.06 & 64.09 & 69.39 & 72.75 & 70.84 & 67.24 \\
\hline Pneumococcal 10 vaccine third dose & 71.03 & 79.46 & 83.34 & 85.88 & 85.17 & 81.40 \\
\hline Meningococcal $C$ vaccine third dose & 73.28 & 81.72 & 84.91 & 88.29 & 87.25 & 83.40 \\
\hline Poliomielitis 1,2,3 vaccine oral dose (VOP) & 65.23 & 74.54 & 79.38 & 79.93 & 80.42 & 76.65 \\
\hline 3-in-1 virus vaccine (MMR or SCR - measles, mumps, rubella) first dose & 92.28 & 98.24 & 96.00 & 94.60 & 96.76 & 96.13 \\
\hline 3-in-1 virus vaccine (MMR or SCR - measles, mumps, rubella) second dose & 63.58 & 69.31 & 78.59 & 82.15 & 78.82 & 74.85 \\
\hline 4-in-1 virus vaccine (SRC+VZ - measles, mumps, rubella, chickenpox) & 55.71 & 39.95 & 46.04 & 69.60 & 68.20 & 50.46 \\
\hline 3-in-1 vaccine (DTP - diphtheria, tetanus, whooping cough) & 91.71 & 96.86 & 97.15 & 97.42 & 100.08 & 96.74 \\
\hline 3-in-1 vaccine (DTP - diphtheria, tetanus, whooping cough) (in children between 4 and 6 years) & 29.79 & 31.91 & 38.54 & 44.48 & 37.86 & 36.17 \\
\hline 3-in-1 vaccine (DTP - diphtheria, tetanus, whooping cough) fourth dose & 64.34 & 73.58 & 75.77 & 76.52 & 75.51 & 74.00 \\
\hline $\begin{array}{l}\text { 2-in-1 vaccine (dT - diphtheria, tetanus in adults) and 3-in-1 vaccine (dTpa - diphtheria, } \\
\text { tetanus, whooping cough acelular) in pregnats }\end{array}$ & 38.15 & 45.16 & 37.23 & 35.76 & 41.88 & 39.75 \\
\hline 3-in-1 vaccine (dTpa - diphtheria, tetanus, whooping cough acelular) in pregnats & 34.38 & 38.36 & 37.58 & 38.56 & 41.80 & 37.93 \\
\hline 4-in-1 vaccine (DTP - diphtheria, tetanus, whooping cough) and Haemaphilus influenzae B & 80.41 & 85.86 & 84.11 & 84.10 & 84.72 & 84.27 \\
\hline TOTAL & 71.64 & 72.94 & 73.54 & 75.69 & 79.47 & 73.91 \\
\hline
\end{tabular}

Source: Unique Health System Information (DATASUS - TABNET), data collected at March 2021 
they have preventable vaccines available in the Immunization Program from the Ministry of Health in Brazil, and their vaccination coverage - Table 1 - that consider just the first age year's vaccine for the national coverage calc - available in the DATASUS site).

The analysed variables were the immunopreventable diseases above-mentioned, year, age groups, gender and economic variables. The partner-demographic data were tabulated and appraised for descriptive statistics (average and percentages, standard deviation SD, confidence interval CI), by the programs Excel $^{\odot}$ (Microsoft Corp., United States version 2007), Stata ${ }^{\circledR}$ (StataCorpLP, College Station, United States version 14.0), and Epi info $7^{\circ}$, by the research team. For the continuous variables (numeric), the analysis of lineal regression was used in the cases of verification of the correlations between the economic variables and immunopreventable disease. It was also analysed the temporary tendencies (Yt) of the economic variables correlated to the hospitalizations, the age groups and the gender, that was defined by the lineal regression equation $\mathrm{Yt}=\mathrm{b} 0+\mathrm{b} 1 \mathrm{t}+\mathrm{et}$. In that expression, the parameter b0 corresponds to a constant, b1 corresponds to the inclination of the straight line and et is a random mistake, by the Prais-Winsten method. When the parameter Beta was positive, the temporary series was considered growing; when negative, it was considered decreasing; and stationary when there was no significant difference between its value and the zero. To measure the tax of variation of the straight line that adjusts the points of the temporary series the logarithmic transformation of base 10 of the coefficients it was accomplished $(\mathrm{Y})$, because it contributes to the reduction of the heterogeneity of the variance for the residues of the analysis of lineal regression.

\section{Results}

It was obtained data regarding 457,479 hospitalizations by immunopreventable disease, in the period from 2008 to 2018, in Brazil [minimum of 275 hospitalizations in the country per year; average of 41,589 ; maximum of 292,209 ; with standard deviation (SD) of $+/-87,366.40$ with 95\% confidence interval (95\% CI) 253.16]. These hospitalizations in the period totaled 2,450,870 days of hospital stay in the period (minimum of 1486 days per year; maximum of 1,271,064 days; average of 222,806.36; SD +/-384,716.64 with 95\% CI 481.64). The total hospitalization costs in this period was $\mathrm{R} \$ 389,243,264.85$ (minimum of $\mathrm{R} \$ 144,992.82$ per year; maximum of $\mathrm{R} \$ 216,785,771.98$; average of $\mathrm{R} \$ 35,385,751.35$; $\mathrm{SD}+/-$ $\mathrm{R} \$ 63,889,745.85$ with 95\% CI R $\$ 6347.00)$; being $\mathrm{R} \$ 340,768,959.48$ regarding the hospital services costs ( $87.55 \%$ of the total value); and $\mathrm{R} \$ 48,471,910.33$ regarding the total professional services costs during the hospitalizations $(12.45 \%$ of the total value of the analysed hospitalizations) (Table 2). These data were updated at DATASUS system site in 2021.

Regarding the regional distribution of Brazil, it was observed that the different geographic areas of the country presented, in this analysed period, several behaviours in relation to each researched disease. The time series analysis (that was represented in the Table 3) demonstrated, in its majority, a stationary tendency of the illness costs in relation to the total of hospitalizations and to their total hospital costs. Some

Table 2 Description of the data regarding the hospitalizations, health care costs (total costs, hospital services and professional services), days of hospital stay and deaths, discriminated by immunopreventable disease, in Brazil, in the period from 2008 to 2018

\begin{tabular}{|c|c|c|c|c|c|}
\hline $\begin{array}{l}\text { Immunopreventable } \\
\text { disease }\end{array}$ & Hospitalization & Total costs & $\begin{array}{l}\text { Hospital services } \\
\text { costs }\end{array}$ & $\begin{array}{l}\text { Professional services } \\
\text { costs }\end{array}$ & $\begin{array}{l}\text { Total days of hospital } \\
\text { stay }\end{array}$ \\
\hline Mumps & 4,097 & $R \$ 961,818.65$ & $\mathrm{R} \$ 808,993.78$ & $R \$ 152,749.07$ & 18,067 \\
\hline Whooping cough & 21,202 & $\mathrm{R} \$ 27,960,510.08$ & $\mathrm{R} \$ 25,295,882.91$ & $\mathrm{R} \$ 2,664,627.17$ & 148,354 \\
\hline Diphtheria & 1,354 & $R \$ 3,140,701.53$ & $\mathrm{R} \$ 2,761,629.70$ & $R \$ 378,883.02$ & 11,970 \\
\hline Yellow fever & 1,993 & $R \$ 2,668,008.64$ & $R \$ 2,366,987.18$ & $R \$ 301,021.46$ & 11,618 \\
\hline Influenza & 292,209 & $R \$ 216,785,771.98$ & $R \$ 188,719,311.10$ & $R \$ 28,065,572.91$ & $1,271,064$ \\
\hline Hepatitis B & 15,415 & $\mathrm{R} \$ 13,038,202.36$ & $\mathrm{R} \$ 11,466,699.57$ & $\mathrm{R} \$ 1,571,401.42$ & 146,890 \\
\hline Meningococcal disease & 24,022 & $\mathrm{R} \$ 47,156,734.49$ & $\mathrm{R} \$ 42,245,572.79$ & $R \$ 4,910,168.46$ & 244,888 \\
\hline Rubella / German measles & 275 & $R \$ 144,992.82$ & $R \$ 122,983.92$ & $R \$ 22,008.90$ & 1,486 \\
\hline Measles & 1,566 & $R \$ 497,605.16$ & $R \$ 419,208.96$ & $R \$ 78,396.20$ & 7,707 \\
\hline $\begin{array}{l}\text { Neonatal and accidental } \\
\text { tetanus }\end{array}$ & 2,208 & $\mathrm{R} \$ 11,547,254.34$ & $\mathrm{R} \$ 10,146,762.21$ & $\mathrm{R} \$ 1,400,492.13$ & 36,581 \\
\hline Chickenpox/Herpes Zoster & 93,138 & $\mathrm{R} \$ 65,341,664.80$ & $R \$ 56,414,927.36$ & $\mathrm{R} \$ 8,926,589.59$ & 552,245 \\
\hline TOTAL & 457,479 & $\mathrm{R} \$ 389,243,264.85$ & $\mathrm{R} \$ 340,768,959.48$ & $\mathrm{R} \$ 48,471,910.33$ & $2,450,870$ \\
\hline
\end{tabular}

Source: Unique Health System Information (DATASUS - TABNET). Period of the collected data from 2008 to 2018 
Table 3 Tendency of the time series analysis from the data regarding the hospitalizations and health care costs (total costs, hospital services and professional services), discriminated by immunopreventable disease and Brazil geographic areas, in the period from 2008 to 2018

\begin{tabular}{|c|c|c|c|c|c|c|c|c|c|c|}
\hline \multirow[t]{2}{*}{ Immunopreventable disease by country areas } & \multicolumn{5}{|c|}{ Hospitalizations } & \multicolumn{5}{|c|}{ Total costs } \\
\hline & $\overline{\text { Beta }}$ & $P$ & \multicolumn{2}{|l|}{$\mathrm{Cl} 95 \%$} & \multirow[t]{2}{*}{ Tendency } & \multirow[t]{2}{*}{$\overline{\text { Beta }}$} & \multirow[t]{2}{*}{$\mathbf{P}$} & \multicolumn{2}{|l|}{$\mathrm{Cl} 95 \%$} & \multirow[t]{2}{*}{ Tendency } \\
\hline Mumps (2008-2018) & & & & & & & & & & \\
\hline BRAZIL & 0.052 & 0.001 & 0.026 & 0.0776 & Growing & 0.067 & 0.000 & 0.046 & 0.088 & Growing \\
\hline CENTER-WEST & 0.043 & 0.023 & 0.007 & 0.079 & Growing & 0.067 & 0.006 & 0.025 & 0.110 & Growing \\
\hline NORTHEAST & 0.058 & 0.000 & 0.035 & 0.079 & Growing & 0.060 & 0.004 & 0.024 & 0.097 & Growing \\
\hline NORTH & 0.090 & 0.000 & 0.061 & 0.119 & Growing & 0.105 & 0.000 & 0.069 & 0.141 & Growing \\
\hline SOUTHEAST & 0.041 & 0.004 & 0.017 & 0.066 & Growing & 0.063 & 0.000 & 0.049 & 0.076 & Growing \\
\hline SOUTH & 0.061 & 0.007 & 0.021 & 0.100 & Growing & 0.065 & 0.001 & 0.032 & 0.099 & Growing \\
\hline \multicolumn{11}{|l|}{ Whooping cough (2008-2018) } \\
\hline BRAZIL & 0.026 & 0.549 & -0.070 & 0.124 & Stationary & 0.033 & 0.468 & -0.065 & 0.132 & Stationary \\
\hline CENTER-WEST & 0.001 & 0.981 & -0.107 & 0.109 & Stationary & 0.005 & 0.920 & -0.106 & 0.116 & Stationary \\
\hline NORTHEAST & 0.061 & 0.229 & -0.046 & 0.168 & Stationary & 0.070 & 0.209 & -0.047 & 0.188 & Stationary \\
\hline NORTH & 0.038 & 0.378 & -0.054 & 0.130 & Stationary & 0.041 & 0.297 & -0.042 & 0.124 & Stationary \\
\hline SOUTHEAST & 0.022 & 0.610 & -0.075 & 0.121 & Stationary & 0.030 & 0.506 & -0.069 & 0.130 & Stationary \\
\hline SOUTH & 0.009 & 0.815 & -0.083 & 0.103 & Stationary & 0.015 & 0.703 & -0.074 & 0.105 & Stationary \\
\hline \multicolumn{11}{|l|}{ Diphtheria (2008-2018) } \\
\hline BRAZIL & -0.029 & 0.018 & -0.052 & -0.0064 & Decreasing & -0.024 & 0.235 & -0.066 & 0.018 & Stationary \\
\hline CENTER-WEST & -0.072 & 0.058 & -0.147 & 0.003 & Stationary & -0.057 & 0.285 & -0.170 & 0.056 & Stationary \\
\hline NORTHEAST & -0.005 & 0.806 & -0.054 & 0.043 & Stationary & 0.007 & 0.844 & -0.078 & 0.093 & Stationary \\
\hline NORTH & -0.054 & 0.180 & -0.139 & 0.030 & Stationary & -0.086 & 0.187 & -0.223 & 0.050 & Stationary \\
\hline SOUTHEAST & -0.039 & 0.001 & -0.056 & -0.021 & Decreasing & -0.042 & 0.001 & -0.064 & -0.021 & Decreasing \\
\hline SOUTH & -0.002 & 0.898 & -0.052 & 0.046 & Stationary & 0.004 & 0.915 & -0.081 & 0.090 & Stationary \\
\hline \multicolumn{11}{|l|}{ Meningococcal disease (2008-2018) } \\
\hline BRAZIL & -0.043 & 0.011 & -0.074 & -0.012 & Decreasing & -0.028 & 0.124 & -0.065 & 0.009 & Stationary \\
\hline CENTER-WEST & -0.033 & 0.010 & -0.056 & -0.01 & Decreasing & -0.029 & 0.094 & -0.066 & 0.006 & Stationary \\
\hline NORTHEAST & -0.030 & 0.096 & -0.068 & 0.006 & Stationary & -0.006 & 0.779 & -0.060 & 0.046 & Stationary \\
\hline NORTH & -0.018 & 0.007 & -0.029 & -0.006 & Decreasing & -0.016 & 0.176 & -0.041 & 0.009 & Stationary \\
\hline SOUTHEAST & -0.055 & 0.012 & -0.095 & -0.015 & Decreasing & -0.039 & 0.072 & -0.083 & 0.004 & Stationary \\
\hline SOUTH & -0.041 & 0.002 & -0.062 & -0.020 & Decreasing & -0.029 & 0.004 & -0.047 & -0.012 & Decreasing \\
\hline \multicolumn{11}{|l|}{ Yellow fever (2008-2018) } \\
\hline BRAZIL & 0.123 & 0.241 & -0.099 & 0.346 & Stationary & 0.182 & 0.206 & -0.120 & 0.484 & Stationary \\
\hline CENTER-WEST & -0.027 & 0.258 & -0.078 & 0.023 & Stationary & -0.131 & 0.564 & -0.629 & 0.366 & Stationary \\
\hline NORTHEAST & 0.031 & 0.467 & -0.061 & 0.123 & Stationary & 0.010 & 0.840 & -0.100 & 0.120 & Stationary \\
\hline NORTH & -0.073 & 0.051 & -0.147 & 0.000 & Stationary & -0.025 & 0.569 & -0.122 & 0.071 & Stationary \\
\hline SOUTHEAST & 0.168 & 0.183 & -0.096 & 0.433 & Stationary & 0.258 & 0.120 & -0.082 & 0.599 & Stationary \\
\hline SOUTH & 0.0008 & 0.985 & -0.102 & 0.104 & Stationary & 0.0008 & 0.989 & -0.134 & 0.135 & Stationary \\
\hline \multicolumn{11}{|l|}{ Influenza (2008-2018) } \\
\hline BRAZIL & -0.023 & 0.001 & -0.034 & -0.013 & Decreasing & -0.019 & 0.014 & -0.033 & -0.0052 & Decreasing \\
\hline CENTER-WEST & -0.077 & 0.002 & -0.116 & -0.037 & Decreasing & -0.065 & 0.007 & -0.106 & -0.023 & Decreasing \\
\hline NORTHEAST & -0.011 & 0.425 & -0.043 & 0.020 & Stationary & -0.004 & 0.801 & -0.047 & 0.038 & Stationary \\
\hline NORTH & -0.005 & 0.523 & -0.026 & 0.014 & Stationary & -0.003 & 0.778 & -0.027 & 0.021 & Stationary \\
\hline SOUTHEAST & -0.034 & 0.037 & -0.066 & -0.002 & Decreasing & -0.026 & 0.124 & -0.060 & 0.008 & Stationary \\
\hline SOUTH & -0.026 & 0.014 & -0.045 & -0.006 & Decreasing & -0.028 & 0.028 & -0.053 & -0.003 & Decreasing \\
\hline \multicolumn{11}{|l|}{ Hepatitis B (2008-2018) } \\
\hline BRAZIL & -0.041 & 0.006 & -0.068 & -0.014 & Decreasing & -0.012 & 0.365 & -0.043 & 0.017 & Stationary \\
\hline CENTER-WEST & -0.026 & 0.078 & -0.057 & 0.0037 & Stationary & 0.011 & 0.445 & -0.021 & 0.045 & Stationary \\
\hline NORTHEAST & -0.028 & 0.084 & -0.061 & 0.0046 & Stationary & -0.008 & 0.575 & -0.041 & 0.024 & Stationary \\
\hline NORTH & -0.055 & 0.038 & -0.106 & -0.0037 & Decreasing & -0.035 & 0.112 & -0.080 & 0.010 & Stationary \\
\hline SOUTHEAST & -0.039 & 0.024 & -0.072 & -0.006 & Decreasing & -0.009 & 0.658 & -0.057 & 0.038 & Stationary \\
\hline SOUTH & -0.061 & 0.005 & -0.099 & -0.024 & Decreasing & -0.038 & 0.054 & -0.077 & 0.0008 & Stationary \\
\hline
\end{tabular}


Table 3 Tendency of the time series analysis from the data regarding the hospitalizations and health care costs (total costs, hospital services and professional services), discriminated by immunopreventable disease and Brazil geographic areas, in the period from 2008 to 2018 (Continued)

\begin{tabular}{|c|c|c|c|c|c|c|c|c|c|c|}
\hline \multirow[t]{2}{*}{ Immunopreventable disease by country areas } & \multicolumn{5}{|c|}{ Hospitalizations } & \multicolumn{5}{|c|}{ Total costs } \\
\hline & Beta & $\mathbf{P}$ & \multicolumn{2}{|l|}{$\mathrm{Cl} 95 \%$} & \multirow[t]{2}{*}{ Tendency } & \multirow[t]{2}{*}{$\overline{\text { Beta }}$} & \multirow[t]{2}{*}{$\mathbf{P}$} & \multicolumn{2}{|l|}{$\mathrm{Cl} 195 \%$} & \multirow[t]{2}{*}{ Tendency } \\
\hline Human rabies virus (2008-2018) & & & & & & & & & & \\
\hline BRAZIL & -0.056 & 0.036 & -0.107 & -0.004 & Stationary & -0.008 & 0.738 & -0.066 & 0.049 & Stationary \\
\hline CENTER-WEST & -0.064 & 0.055 & -0.131 & 0.0018 & Stationary & -0.200 & 0.187 & -0.517 & 0.116 & Stationary \\
\hline NORTHEAST & -0.085 & 0.010 & -0.145 & -0.025 & Decreasing & -0.057 & 0.120 & -0.133 & 0.018 & Stationary \\
\hline NORTH & 0.061 & 0.085 & -0.010 & 0.134 & Stationary & 0.246 & 0.177 & -0.133 & 0.626 & Stationary \\
\hline SOUTHEAST & -0.067 & 0.332 & -0.215 & 0.081 & Stationary & -0.036 & 0.768 & -0.305 & 0.233 & Stationary \\
\hline SOUTH & -0.077 & 0.228 & -0.212 & 0.057 & Stationary & -0.102 & 0.516 & -0.445 & 0.2400 & Stationary \\
\hline \multicolumn{11}{|l|}{ Rubella / German measles (2008-2018) } \\
\hline BRAZIL & -0.056 & 0.002 & -0.086 & -0.025 & Decreasing & -0.049 & 0.217 & -0.133 & 0.034 & Stationary \\
\hline CENTER-WEST & -0.052 & 0.064 & -0.109 & 0.0036 & Stationary & -0.207 & 0.031 & -0.391 & -0.024 & Decreasing \\
\hline NORTHEAST & -0.055 & 0.062 & -0.114 & 0.0035 & Stationary & -0.050 & 0.051 & -0.100 & 0.0003 & Stationary \\
\hline NORTH & -0.034 & 0.126 & -0.080 & 0.0117 & Stationary & -0.164 & 0.106 & -0.372 & 0.043 & Stationary \\
\hline SOUTHEAST & -0.069 & 0.003 & -0.108 & -0.029 & Decreasing & -0.047 & 0.036 & -0.091 & -0.003 & Decreasing \\
\hline SOUTH & -0.031 & 0.188 & -0.081 & 0.018 & Stationary & -0.029 & 0.296 & -0.088 & 0.030 & Stationary \\
\hline \multicolumn{11}{|l|}{ Measles (2008-2018) } \\
\hline BRAZIL & 0.035 & 0.342 & -0.044 & 0.115 & Stationary & 0.039 & 0.126 & -0.013 & 0.092 & Stationary \\
\hline CENTER-WEST & -0.122 & 0.011 & -0.208 & -0.036 & Decreasing & -0.132 & 0.270 & -0.388 & 0.122 & Stationary \\
\hline NORTHEAST & 0.050 & 0.067 & -0.004 & 0.104 & Stationary & 0.081 & 0.009 & 0.0264 & 0.136 & Growing \\
\hline NORTH & 0.020 & 0.515 & -0.049 & 0.090 & Stationary & -0.093 & 0.004 & -0.146 & -0.040 & Decreasing \\
\hline SOUTHEAST & -0.028 & 0.364 & -0.096 & 0.038 & Stationary & -0.034 & 0.171 & -0.086 & 0.017 & Stationary \\
\hline SOUTH & -0.061 & 0.289 & -0.185 & 0.062 & Stationary & -0.063 & 0.369 & -0.215 & 0.088 & Stationary \\
\hline \multicolumn{11}{|l|}{ Neonatal and accidental tetanus (2008-2018) } \\
\hline BRAZIL & -0.003 & 0.224 & -0.009 & 0.002 & Stationary & 0.013 & 0.079 & -0.0018 & 0.028 & Stationary \\
\hline CENTER-WEST & 0.0007 & 0.941 & -0.019 & 0.021 & Stationary & -0.008 & 0.697 & -0.053 & 0.037 & Stationary \\
\hline NORTHEAST & -0.006 & 0.599 & -0.033 & 0.020 & Stationary & 0.014 & 0.127 & -0.0051 & 0.035 & Stationary \\
\hline NORTH & -0.008 & 0.446 & -0.031 & 0.015 & Stationary & 0.031 & 0.225 & -0.022 & 0.085 & Stationary \\
\hline SOUTHEAST & 0.006 & 0.444 & -0.012 & 0.025 & Stationary & 0.014 & 0.344 & -0.018 & 0.049 & Stationary \\
\hline SOUTH & -0.003 & 0.765 & -0.021 & 0.017 & Stationary & 0.009 & 0.102 & -0.002 & 0.022 & Stationary \\
\hline \multicolumn{11}{|l|}{ Chickenpox/Herpes Zoster (2008-2018) } \\
\hline BRAZIL & -0.037 & 0.000 & -0.045 & -0.029 & Decreasing & -0.021 & 0.012 & -0.036 & -0.006 & Decreasing \\
\hline CENTER-WEST & -0.043 & 0.007 & -0.071 & -0.015 & Decreasing & -0.030 & 0.107 & -0.068 & 0.007 & Stationary \\
\hline NORTHEAST & -0.011 & 0.016 & -0.021 & -0.002 & Decreasing & 0.022 & 0.000 & 0.015 & 0.028 & Growing \\
\hline NORTH & -0.032 & 0.034 & -0.061 & -0.002 & Decreasing & -0.056 & 0.010 & -0.095 & -0.017 & Decreasing \\
\hline SOUTHEAST & -0.040 & 0.000 & -0.049 & -0.031 & Decreasing & -0.025 & 0.032 & -0.048 & -0.002 & Decreasing \\
\hline SOUTH & -0.049 & 0.008 & -0.081 & -0.016 & Decreasing & -0.038 & 0.103 & -0.087 & 0.009 & Stationary \\
\hline
\end{tabular}

Source: Unique Health System Information (DATASUS - TABNET). Period of the collected data from 2008 to 2018

particularities were observed, as in the case of the disease mumps that presented growing tendency in all areas, with significant statistical $(p<0.05)$. The whooping cough came with stationary tendency (neither growing nor decreasing) in all areas in the period, the same case of yellow fever and tetanus (neonatal and accidental). Some sickness presented variations among the distributions in the different areas, like the case of diphtheria (that presented decreasing tendency in the Southeast and stationary in the other areas). The hospitalizations caused by influenza were decreasing in the Center-west, in the
Southeast and in the South, and the total values of their hospitalizations were decreasing in the same States: Center-west and in the South. The total of hospitalization for hepatitis B declined in the North, South and Southeast, though, the total values of these hospitalizations were shown stationary in the period in all the country. The total of cases of meningococcal disease presented decreasing tendency in all areas in the period, except in the Northeast, though, the total values of these hospitalizations tended to decline only in the South area. The cases of hospitalizations for human rabies virus hospitalized had a decreasing 
tendency only in the Northeast, staying stationary during the period analysed in the other areas. In the case of the hospitalizations for German measles / rubella, both the total of internments and their total values tended to decrease only in the Southeast area, being shown a stationary tendency in the other areas of the country. The sickness measles came in very several ways of the others: the amount of hospitalizations came registered in system in a decreasing way in the area Center-west and shown a stationary tendency in the other areas; and the values associated its hospitalizations came growing in the Northeast (with $p$-value 0.009 and CI95\% between 0.0264 and 0.136 ), decreasing in the North and in the other areas a stationary tendency. The sickness Chickenpox / Herpes Zoster showed a decreasing tendency of the total of hospitalizations in all the areas of the country in the period analysed (with statistical significance), though the total values of the hospitalizations came growing in the Northeast (with p-value 0.000 and C195\% between 0.015 and 0.028), decreasing in the North area ( $p$-value 0.010 and CI95\% between -0.095 and 0.017 ) and in the Southeast (p-value 0.032 with CI95\% between -0.048 and -0.002 ).

\section{Discussion}

The immunopreventable diseases answer for half of all the deaths in countries with smaller development index: $90 \%$ of these deaths attributed to diarrheal diseases, breathing diseases, AIDS, tuberculosis, malaria and measles [12, 14-16], and many of them could be preventable through the vaccines. Based on the data collected in this research, still today citizens get sick and are hospitalized by immunopreventable diseases. As we observed in in this study, there were 457,479 hospitalizations in the period from 2008 to 2018, in Brazil with a budget impact of $\mathrm{R} \$ 389,243,264.85$. According to the Ministry of Health data (https://saude. gov.br/noticias/agencia-saude/45877-secretary-nationalof-surveillance-in-greet-speech-on-supply-and-budgetfor-vaccine-haul-of-investment-for-to-area), the budget destined to PNI corresponds to $53 \%$ of the general budget of the Health Surveillance Secretariat. This budget destined for purchase vaccines and inputs related to immunization totalized $\mathrm{R} \$ 45.3$ billion, according to the Annual Budget Bill (PLOA) of 2020. Considering the total budget of SUS R $\$ 147,43$ billion for the health care in 2019, according to data of the Brazilian Office of Comptroller General(CGU) (http:// www.portaltransparencia.gov.br/funcoes/10-saude?ano= 2019), the expenses with immunopreventable disease hospitalizations are inside the total of $\mathrm{R} \$ 114.18$ billion of expenses executed for the area of the health (for hospital and outpatient care). In this context, analysing the direct costs with hospitalizations related to the immunopreventable diseases in SUS, it was observed the reflex of the actions of the public politics of health indirectly, mainly in the country, independent of the regional differences that knowingly exist. If was observed the total expenses here lifted, it is possible saving more than $\mathrm{R} \$ 389$ million avoiding diseases that can be forewarned for measures effective and thoroughly accessible for every Brazilian population $=$ the vaccines.

Another observed interesting data is the fact that the hospitalizations for the immunopreventable disease didn't decline in uniform way in the different country's areas, and some illness until presented growing tendencies (as mumps, for instance). This situation should be analysed with very carefully, because it raises the existence of regional differences among health care quality, services structures installed, social inequalities that impact in the population's health, and differences in the regional public politics of facing each immunopreventable disease (despite the national politics of prevention, promotion, diagnosis and treatment of each illness) [17-24].

Nowadays, the financial resources are being destined to the hospitalizations of Immunopreventable diseases can be forewarned with effective measures as the vaccines, if the population was appropriately vaccinated, these resources could be used for other situations, so many needs of public health. This manuscript brings an opportunity for improvement that is the importance of employing awareness public and private campaigns for the importance of increase the vaccination coverage in all geographic areas (Table 1), regarding the regional differences (differences in vaccination's culture, health services access, health budget, health services territorial distribution, and many differences in the population reality that differ between the Brazilian geographic area).

All studies based on public secondary databases have the limitation, already known, of under-reporting and under-reporting of the analysed system itself, because these are dependent on the databases being fed by the employees responsible for the system. In the case of the SUS, these data are feeders in a decentralized manner and regionalized by States and Municipalities. However, despite the notorious underutilization of the system, these are the official data that are used for the development of public health policies in Brazil.

\section{Acknowledgements \\ No acknowledgements to declare.}

\section{Authors' contributions}

The authors (ESMC; AD; EMCPM) are responsible for the study data, the methodology, the data analysis, the literature revision, and the study conclusions. The author(s) read and approved the final manuscript. 


\section{Funding}

The authors didn't receive any funding sources.

\section{Availability of data and materials}

The data that support the findings of this study are openly available in the information system website of the Department of the Unified Health System (DATASUS - http://www2.datasus.gov.br/DATASUS/index.php?area=02).

\section{Declarations}

\section{Ethics approval and consent to participate}

This study was submitted and accepted by the Ethical Committee by the Federal University of Paraná, at the number CAAE 15102619.6.0000.0102.

\section{Consent for publication}

The authors responsible for this study consents in publication. The consent obtained from participants it was not applicable at this study because the data used are secondary cluster public data.

\section{Competing interests}

There are not competing interests by the authors.

\section{Author details}

${ }^{1}$ Department of Internal Medicine Post-graduation, Federal University of Paraná, General Carneiro Street, 181, Curitiba, Paraná, Brazil. ${ }^{2}$ Internal Medicine, Federal university of Paraná (UFPR), Health Management by Superior Institute of Management and Economy / Getúlio Vargas Foundation (ISAE/FGV), Curitiba, Brazil. ${ }^{3}$ Pos-geraduation Program in Internal Medicine, Federal University of Paraná (UFPR), Curitiba, Brazil.

Received: 28 June 2021 Accepted: 23 September 2021 Published online: 27 October 2021

\section{References}

1. World Health Organization (WHO). International travel and health. Chapter 6. Available at: https://cdn.who.int/media/docs/default-source/travel-andhealth/9789241580472-eng-chapter-6.pdf?sfvrsn=8c1a400c_14. Accessed in 06/04/2021.

2. Brazil. Ministério da Saúde. Secretaria de Vigilância em Saúde. Departamento de Vigilância das Doenças Transmissíveis. Manual de normas e procedimentos para vacinação / Ministério da Saúde, Secretaria de Vigilância em Saúde, Departamento de Vigilância das Doenças Transmissíveis. - Brasília: Ministério da Saúde; 2014. Available at https:// bvsms.saude.gov.br/bvs/publicacoes/manual_procedimentos_vacinacao.pdf. Accessed in 06/04/2021.

3. Brasil. Ministério da Saúde. Secretaria de Vigilância em Saúde. Departamento de Vigilância das Doenças Transmissíveis. Manual de rede de frio do Programa Nacional de Imunizações / Ministério da Saúde, Secretaria de Vigilância em Saúde, Departamento de Vigilância das Doenças Transmissíveis. - 5. ed. - Brasília: Ministério da Saúde; 2017.

4. Bloom DE, Canning D, Weston M. The value of vaccination. World Econ; 2005; 6(3):15-39. Available at http://portalarquivos2.saude.gov.br/images/pdf/2017/ dezembro/15/rede_frio_2017_web_VF.pdf. Accessed in 06/04/2021.

5. Andre FE, Booy R, Bock HL, Clemens J, Datta SK, John TJ, et al. Vaccination greatly reduces disease, disability, death and inequity worldwide. Bull World Health Organ; 2008;86(2):140-146. Available at https://www.who.int/bulletin/ volumes/86/2/07-040089/en/. Accessed in 06/04/2021.

6. Plotkin S. History of vaccination. PNAS. Special Issue, 2014; 111(34): 1228312287. Avilable at https://www.pnas.org/content/pnas/111/34/12283.full.pdf. Accessed in 06/04/2021.

7. Dabbagh A, Eggers R, Cochi S, Dietz V, Strebel P, Cherian T. World Health Organization. A new global framework for immunization monitoring and surveillance. Available at: https://www.who.int/bulletin/volumes/85/12/07-04 8223.pdf. Accesed in 06/04/2021.

8. Omer SB, Salmon DA, Orenstein WA, De Hart MP, Halsey N. Vaccine refusal, mandatory immunization, and the risks of vaccine-preventable diseases. N Engl J Med. 2009;360(19):1981-1988. Available at: https://doi.org/10.1056/ NEJMsa0806477. Accessed in 06/04/2021.

9. Pezzotti P, Bellino S, Prestinaci F, lacchini S, Lucaroni F, Camoni L, et al. The impact of immunization programs on 10 vaccine preventable diseases in italy: 1900-2015. Vaccine. 2018;36(11):1435-1443. Available at https://www.
sciencedirect.com/science/article/pii/S0264410X18301269. Accessed in 06/ 04/2021.

10. Australia Government. Department of Health. Discussion paper: towards a national communicable disease control framework [Internet].

Commonwealth of Australia 2014 [cited 2021 Jun 2] Available at <https:// www.health.gov.au/internet/main/publishing.nsf/content/e5134f29919e9d74 ca257cfb0082c7c5/\$file/discussion-paper.pdf> Accessed in 06/04/2021.

11. Mclaughlin JM, McGinnis JJ, Tan L, Mercatante A, Fortuna J. Estimated human and economic burden of four major adult vaccine-preventable diseases in the United States, 2013. J Primary Prev. 2015;36(4):259-273. DOI https://doi.org/10.1007/s10935-015-0394-3. Available at https://pubmed.ncbi. nlm.nih.gov/26032932/. Accessed in 06/04/2021.

12. Stack ML, Ozawa S, Bishai DM, Mirelman A, Tam Y, Niessen L, et al. Estimated Economic Benefits During The 'Decade of Vaccines' Include Treatment Savings, Gains in Labor Productivity. Health Aff (Millwood). 2011 ; 30(6):1021-1028. Available at https://doi.org/10.1377/hlthaff.2011.0382. Accessed in 06/04/2021.

13. Brazil. Ministério da Saúde. Secretaria de Vigilância em Saúde. Departamento de Vigilância Epidemiológica. Programa Nacional de Imunizações (PNI): 40 anos / Ministério da Saúde, Secretaria de Vigilância em Saúde, Departamento de Vigilância Epidemiológica. - Brasília: Ministério da Saúde; 2013. Available at https://bvsms.saude.gov.br/bvs/publicacoes/ programa_nacional_imunizacoes_pni40.pdf. Accessed in 06/04/2021.

14. Ehreth J. The global value of vaccination. Vaccine. 2003;21(7-8):596-600. Available at https:/pubmed.ncbi.nlm.nih.gov/14505886/. Accessed in 06/04/2021.

15. MacLennan CA. Vaccines for low-income countries. Sem Immunol 2013; 25(2):114-123. Available at https://pubmed.ncbi.nlm.nih.gov/23757292/. Accessed in 06/04/2021.

16. World Health Organization (WHO). The global burden of disease: 2004 update; 2012. Available at https://www.who.int/healthinfo/global_burden disease/2004 report update/en/. Accessed in 06/04/2021.

17. World Health Organization (WHO). Surveillance standards for vaccinepreventable diseases, second edition. Geneva: World Health Organization; 2018. Available at https://www.who.int/immunization/monitoring_surveilla nce/burden/vpd/standards/en. Accessed in 06/04/2021.

18. Brazil. Ministério da Saúde. Gabinete do Ministro. Portaria n. 204, de 17 de fevereiro de 2016. Define a Lista Nacional de Notificação Compulsória de doenças, agravos e eventos de saúde pública nos serviços de saúde públicos e privados em todo o território nacional, nos termos do anexo, e dá outras providências [Internet]. Diário Oficial da União; 2016 [citado 2021 Jun 4]. Disponível em: vailable at: http://bvsms.saude.gov.br/bvs/saudelegis/ gm/2016/prt0204_17_02_2016.html. Accessed in 06/04/2021.

19. Brazil. Ministério da Saúde. Secretaria de Vigilância em Saúde. CoordenaçãoGeral de Desenvolvimento da Epidemiologia em Serviços. Guia de Vigilância em Saúde [Internet]. Volume único [recurso eletrônico] / Ministério da Saúde, Secretaria de Vigilância em Saúde, Coordenação-Geral de Desenvolvimento da Epidemiologia em Serviços. 3a ed. Brasília (DF): Ministério da Saúde; 2019 [citado 2021 Jun 4]. Disponível em: http://bvsms.saude.gov.br/bvs/publicacoes/ guia_vigilancia_saude_3ed.pdf Accessed in 06/04/2021.

20. Ozawa S, Portnoy A, Getaneh H, Clark S, Knoll M, Bishai D, et al. Modeling The Economic Burden of Adult Vaccine-Preventable Diseases in the United States. Health Aff (Millwood). 2016;35(11):2124-2132. Available at https:// pubmed.ncbi.nlm.nih.gov/27733424/. Accessed in 06/04/2021.

21. Witte JJ, Axnick NW. The Benefits From 10 Years of Measles Immunization in the United States. Public Health Rep. 1975;90(3):205-207. Available at https://pubmed.ncbi.nlm.nih.gov/807933/. Accessed in 06/04/2021.

22. Global Alliance for Vaccines and Immunization (GAVI). The Impact of Immunization on Economic Development. Press information. Available at http://www.vaccinealliance.org/ Accessed in 06/04/2021.

23. World Health Organizaion (WHO). Eradication versus control: the economics of global infectious disease policies [Internet]. Bulletin of the World Health Organization: WHO; 2004 [cited 2021 Jun 4]. Available from: https://www.who. int/bulletin/volumes/82/9/barrett0904abstract/en/. Accessed in 06/04/2021.

24. Brazil. Ministério da Saúde. Sobre o Programa. Available at https://antigo.saude. gov.br/saude-de-a-z/vacinacao/sobre-o-programa Accessed in 06/04/2021.

\section{Publisher's Note}

Springer Nature remains neutral with regard to jurisdictional claims in published maps and institutional affiliations. 